\title{
Mapping new philanthropy and the heterarchical state: the Mobilisation for the National Learning Standards in Brazil
}

\begin{abstract}
In this paper we focus on one specific case to explore how networks of governance and concomitant processes of "heterarchicalisation" operate in practice in education. We analyse the relationship between the Brazilian Federal Government and an advocacy coalition for a standard curriculum named Mobilisation for the National Learning Standards (MNLS). We employ network ethnography, with social network graphs, interviews and fieldwork, to establish how MNLS has been configured as a space of collaboration between new philanthropy and the state, and as a policymaking space in its own right. We explore how this space and the network of relations that constitute it can be seen as one example of the heterarchical state in practice, illustrating how, within such a heterarchy, new policy spaces are created, developed and reconfigured over time. We also hope to demonstrate how the method of network ethnography can facilitate the analysis of such policy spaces and networks.
\end{abstract}

\section{Introduction}

Changing relationships between the state and society are an international phenomenon, in spite of considerable variation. Generally speaking states now increasingly share the work of governing with other social actors (Bevir, 2011). Decision making processes and implementation systems that used to be mainly executed by the state are increasingly dispersed in complex networks of non-governmental institutions and agencies. While the boundaries between the state, economy and civil society have always been thin and fuzzy, relations across those boundaries have assumed a new stridency and intensity in the past 30 years (Ball and Junemann, 2012). In this context, philanthropy is also changing. The so-called "new philanthropy" treats donations as investments, results as returns, and wants to be involved in decisions about how money is used and consequently "is bringing new players into the field of social and education policy, repopulating and reworking existing policy networks." (Ball and Olmedo, 2011, p. 83). Here the social/moral and financial are tightly intertwined, and articulated in terms of social need, risk and returns, in relation to scale and sustainability. Philanthropies of various kinds are taking on the moral responsibilities of the state articulated within a complex global architecture of economic and social relations. 
To explore how such networks of governance operate in practice and to illustrate the concomitant processes of the "heterarchicalisation" of the state, in this paper we focus on one specific case. We analyse the relationship between the Brazilian advocacy coalition for a standard curriculum named Movimento pela Base Nacional Comum, or Mobilisation for the National Learning Standards (MNLS), and the federal government. We will focus on how MNLS has been configured as a space for collaboration between new philanthropy and the state, and as a policymaking space in its own right.

Researchers have begun to address the work of new philanthropy in education policy making, and the joint remaking of the state and its new forms of governance in different countries (Adrião et al, 2005; Au \& Ferrare, 2015; Ball \& Junemann, 2012; Freitas, 2012; Hogan et al, 2015; Olmedo, 2014; Peroni, 2013; Reckhow \& Snyder, 2014; Robertson \& Verger, 2014). We draw on this literature and aim to contribute to it. To achieve it, we make use of network ethnography as the appropriate method for the identification and analysis of the construction, maintenance and evolution of policy networks. The aim is to "open up a set of issues, rather than to provide a definitive account" (Lingard et al, 2014, p. 711).

First we introduce the theoretical and methodological tools upon which we draw by discussing the relation between the reworking of the state from government to governance and its operation in the form of heterarchies, with the method of network ethnography. Second, we present some contextual information about the Brazilian public management of education and the debate about curriculum in the country. Third, we introduce the MNLS and address it in three ways. We first look at the movement's creation, accounting for its ideals and its use of seminars to promote purposeful meetings with and between relevant education policy actors from the government and new philanthropy. Then we explore MNLS's composition by analysing the co-affiliations evident in MNLS's network. Finally, we analyse the network changes between MNLS and education federal authorities in Brazil between 2015 and 2016. This involves attention to some of the key players in collaboration around this particular initiative and a glimpse into the "prosaic netherworlds of policy implementation" (Peck \& Theodore, 2012, p. 24). To conclude, we discuss how MNLS and its relation with the Brazilian government can be seen as one example of the heterarchical state in practice, illustrating how new policy spaces are created, developed and reconfigured over time; as well as how network ethnography can facilitate the analysis of such policy spaces and networks. Our analysis indicates the changing nature of state work, the blurring of the boundaries between philanthropy and politics and the insertion into education policy of new sensibilities and interests. We also signal some of the ways in which policy ideas are moved inter and intra nationally. 


\section{Using network ethnography to study policy networks and heterarchies: theoretical and methodological considerations}

In theoretical and methodological debates in political studies, a contrast is drawn between government, done through hierarchical bureaucracies, and governance, accomplished through diverse and flexible networks (Ball \& Junemann, 2012; Rhodes, 1996). A new mix between state, market and philanthropy is being created, in which the three elements are also reworked. The state is being reworked as a market-maker, commissioner of services and performance monitor. The market is expanding to increasingly subject the social and the public to the rigours of profit. Philanthropy is being reworked by the discourses and sensibilities of business, adopting, for example, practices of impact, assessment, efficiency and competition (Ball \& Olmedo, 2011; Bishop \& Green, 2010).

The governance literature distinguishes three main forms of coordination or reciprocal interdependence: the "anarchy" of the market, the hierarchy of a firm or state, and the selforganisation of the heterarchy (Jessop, 2011). In other words, a heterarchy is "an organisational form somewhere between hierarchy and network that draws upon diverse horizontal and vertical links that permit different elements of the policy process to cooperate (and/or compete)" (Ball and Junemann, 2012, p.138). In this new mix of markets, networks and hierarchies, new personal and professional connections across different institutions and sectors - public, private and voluntary - are established. Careers are forged in movement between and across these sectors by boundary-spanners, people who bring "unlikely partners together" break "through red tape", and see "things in a different way" (Williams, 2002, p.109). Several such boundaryspanners are identified below.

Our response to and engagement with the shifts outlined above are set within "a broad set of epistemological and ontological shifts across political science, sociology and social geography which involve a lessening of interest in social structures, and an increasing emphasis on flows and mobilities (of people, capital and ideas)" (Ball, 2012, p. 5). Urry (2003) refers to this as the "mobility turn". Attention is given to new configurations of social life and relations, which are increasingly "networked" (Urry, 2003). The term "network" is deployed here in a dual sense: as a conceptual device that is used to "represent a set of "real" changes in the forms of governance of education, both nationally and globally", and as a method, "an analytic technique for looking at the structure of policy communities and their social relationships" (Ball, 2012, p. 6). 
Network ethnography is an appropriate and responsive method that engages with "networks" in both senses (see Au \& Ferrare, 2015; Ball \& Junemann, 2012; Hogan et al., 2015; Olmedo, 2017; Santori, Ball, \& Junemann, 2015; Shiroma, 2013). Network ethnography is an assemblage of research tactics and techniques that addresses both the organisation and processes of network relations. On the one hand, it draws from social networks analysis (SNA), focussing on social relations between people and institutions and the basic data represent such relations (usually in the form of network graphs) (Prell, 2012). In this paper we made use of affiliation networks, as well as network dynamics to understand the operation and development of MNLS's network. On the other hand, network ethnography departs from SNA in its search for the meaning and context of these relations, which are often lost or remain unaddressed in more orthodox versions of SNA (Knox et al, 2006).

In SNA, the term "affiliations" usually refers to membership or participation data and co-affiliations are "opportunities for things like ideas to flow between actors", and "affiliations data consist of a set of binary relationships between members of two sets of items" (Borgatti \& Halgin, 2012, p. 417). So the data is represented in two sets, in this case a set of people and a set of institutions, with a relation that connects them, in this case "being a member of". In affiliation graphs, there are only connections across sets, and no connections within a set. So a person can be connected to many institutions (as "being a member of" many institutions), but not to other people. Similarly, institutions can be connected to many people, but not directly connected to other institutions. Here, the data concerns MNLS individual members and the institutions to which they are affiliated through professional work, which has been collected online in a variety of websites (mainly institutional websites and publicly available personal $\mathrm{CVs}$ ). In this regard, "an important advantage of affiliation data, especially in the case studying elites, is that affiliations are often observable from a distance (e.g., government records, newspaper reports), without having to have special access to the actors." (Borgatti \& Halgin, 2012, p. 417).

When one is interested in the relationship between one part of the set, such as the relation between institutions - rather than between people and institutions - "we can in fact construct some kind of tie among members of a node set simply by defining co-affiliation (e.g., attendance at the same events, membership on the same corporate board) as a tie. Thus, affiliations data give rise to co-affiliation data, which constitute some kind of tie among nodes within a set." (Borgatti and Halgin, 2012, p. 423). Accordingly, in this paper we have converted a dual-mode network (person-by-institution) into a co-affiliation one-mode network 
(institution-by-institution), assuming that two institutions that have a member in common have a significant chance of ideas being exchanged from one to the other.

Identifying and categorizing these affiliations was challenging at times. These professionals have mobile and boundary-spanning careers (Larner \& Laurie, 2010), some pursue more than one occupation, and others change jobs rather quickly. Thus, the graphs are a static oversimplified representation of complex and fast-changing network relations (Ball and Junemann, 2012). The affiliations considered refer to the individual's main employment, but in some cases two affiliations for one individual were included when these were meaningful policy-making roles (such as a being part of a municipal consultative body).

Complementarily, we employed a combination of mapping, visiting and questioning and as Marcus (1995) puts it - following policy. This following is both virtual (through the internet and social media) and face-to-face (interviews with network actors and attendance at network events). It involves following people and "things", as well as metaphors, plots, lives, conflicts, and "money" (Junemann et al. 2015; Santori et al. 2016). It involves close attention to organisations and actors within the education policy field, both global and local (and their movement), as well as to the chains, paths and connections that join-up these actors, and to "situations" and events in which policy knowledge is mobilized and assembled. This means looking at the "whos" and "whats" and "wheres" of policy, the places and events in which the "past, present and potential futures of education co-exist" (McCann \& Ward, 2012, p. 48). As regards the "wheres", as McCann and Ward (2012 p. 42) put it, this means both "following policies and "studying through" the sites and situations of policymaking". As regards the "whos", they explain: "our work asks how policy actors circulate policies among cities, how they draw on circulating policy knowledge and how and for whom they put these engagements to use as they assemble their own "local" policies..." (p. 42). All of this requires "staying close to practice" (McCann and Ward, 2012, p. 45). It also means that network ethnographers must become what Burawoy (2000 p. 4) calls global ethnographers, that is, "become the living embodiment of the processes we are studying". As network researchers we travel, we attend, we meet, we network - in order to research networks. Our practice is homologous to/with the networks researched.

In this case, the network ethnography has involved deep and extensive Internet searches focused on MNLS, its institutional and individual members, and related events. This included visiting countless webpages (including all MNLS institutional members, the Ministry of Education - MEC, the National Council of Education - NCE, Yale University etc.), personal $\mathrm{CVs}$, newspapers and related social media, blogs, and documents (such as official notes from 
MEC, NCE and the Deputy Chamber). MNLS's institutional website was also examined with support of an Internet archive ${ }^{1}$ to access the list of the MNLS's individual members in different points in time. The data collected in these sources informed the building of network graphs and the selection of institutions and people to be interviewed, specifically those identified as highly connected and influential in MNLS. Interviews were conducted with representatives of Lemann Foundation and Natura Institute - both institutional supporters and funders of MNLS, who were directly approached via email.

What is offered here is a set of snapshots in the construction and evolution of a fastchanging set of policy relationships and initiatives. Over and against the conceptualisation of networks as dynamic and evolving, there is a constant struggle against flatness, "finishedness" and order in their analysis and representation. Effort and imagination are needed within research writing to maintain a sense of the "thrown-togetherness" and labour of networks and their evolution. We attempt to capture something of this in the time series data presented below.

\section{The Context: curriculum in the federation of Brazil}

Before we attend to the work of the MNLS in Brazil, and its relation with civil servants, we will present a short account of the Brazilian federal government, as well as the on-going curriculum debate in the country to localise our analysis. In Brazil, within set of a complex federal relations, the national government interacts with 27 states and 5570 municipalities. Education is a shared responsibility between the federal entities, according to the 1996 Education Act, named Law of Directions and Basis of Education (LDB96). Education management at the federal level is represented by the Ministry of Education (MEC in Portuguese), which creates the national guidelines for all other entities, including for example regulations on funding and the National Education Plan. The federal level also holds the main responsibility for higher education.

To begin to understand the close relation between the MNLS and MEC, it is important to note that MEC has two main decision-making spaces, the Minister's Office and the National Council of Education (NCE), which might be understood as mirroring a president and a house of representatives. The NCE is composed of two chambers, the chambers of "basic education" and "higher education", each one with 11 members. In MEC's hierarchy, below the Minister and the council, there are 6 secretariats, amongst which the Secretariat of Basic Education

\footnotetext{
${ }^{1}$ In this paper the authors used the internet archive waybackmachine.org
} 
(SEB) is the most significant in relation to the new curriculum. Alongside the federal government, states are mainly responsible for the second half of primary education and for secondary education (both are still part of the so-called "Basic Education"). Finally, municipalities are responsible for the first half of primary schooling and early years education. States and municipalities have relative autonomy within federal guidelines to decide upon different matters such as funding, curriculum, teaching methods, hiring teachers and developing their own public-private partnerships.

In this scenario, the debate around a national curriculum in Brazil is not new. There has been an on going debate since 1997, when the process of elaborating a national curriculum was begun during the government of Fernando Henrique Cardoso. The proposed reform was at that time named National Curricular Parameters (NCP), and the NCE was charged with creating these parameters. In a broader perspective, at the time, there was an international movement towards centralised curricula, in Europe, Australia, the USA, and with similar debates evident in Latin America and Africa (Macedo, 2014, 2016). In these latter regions the World Bank and the Banco Interamericano de Desenvolvimento (BID, or Interamerican Bank of Development) wrote documents with guidelines that clearly encouraged the centralisation of curriculum and assessment (BID, 1998; Tommazi, Ward e Haddad, 1996; in Macedo, 2016). However, in Brazil there was also criticism of and resistance to a centralised curriculum, especially from academics and teacher unions. Particularly so because the country was going through the process of "redemocratisation" (the military dictatorship officially ended in 1985 and the new Federal Constitution was written in 1988) and decentralised policies were seen as more democratic (Arretche, 1996). The NCE, then, developed a somewhat generic document with curricular guidelines that were proposed but not imposed for local authorities, thus maintaining states and municipalities' autonomy over their curricula (Macedo, 2016).

However, between 2008 and 2010, MEC created more detailed instructions in the form of a five-volume document named "Indagações Curriculares", although this did not articulate a comprehensive "curriculum" as such (Macedo, 2016). At the same time, the National Plan for Education was being discussed, a national document with aims and goals for the following 10 years. After a long debate and with a wide participation of civil society, the plan was signed in 2014 with an apparent consensus about the need of national common basis for the curriculum: "Thus, 20 years after the first attempt of establishing a national curriculum in Brazil, it seems the dispute is coming to its end. [...] Although the federal system has its set of shared responsibilities, the process of national curricular centralisation seems to have become hegemonic" (Macedo, 2016, p. 6). 
From 2014, once the National Plan for Education had established the National Curricular Common Base (from here on referred to as simply "Base") as a "strategy for improving education in Brazil" the debate about the form and content of this Base gained momentum and increased public attention. We want to focus on one of the most prominent participants in this debate, which is the group named Mobilisation for the National Learning Standards (MNLS, or simply "Movement"). The MNLS is one of many new "complex and contradictory spaces ripe for critical interrogation" (Peck \& Theodore, 2012, p. 21). In the next section we will explore what this group is, its goals, how it was created and its composition.

\section{MNLS's creation: shared beliefs in new policymaking spaces}

The Mobilisation for the National Learning Standards describes itself as an "advocacy movement" with a diverse membership that sees a standard curriculum as "a crucial step to promote educational equity and align the educational system elements in Brazil”. For the Movement, creating this curriculum will work as "a dorsal spine for the learning rights of each student, for teacher training, for teaching materials and external assessments" (MNLS institutional website). Concisely, in their principles they claim the Base must be focused on the essential knowledge, skills and values; be clear and objective; be underpinned by "research evidence" and be mandatory for all schools in the country. On the other hand, they claim the Base should have diversity, respect the autonomy of the federal entities to build their curricula and that the Base should be elaborated in a collaboration between federal, state and municipal governments (MNLS institutional website ${ }^{2}$ ).

The MNLS consists of a somewhat loose network of individuals and organisations, a discourse community focused on the need for education reform, made up of policy entrepreneurs, traveling technocrats and "thought leaders" offering solutions to education policy "problems". The members, in various ways claim a certain expertise and they are enacting particular forms of what Mitchell (2002) calls "techno-politics", they link expert knowledges to political power in diverse and distinctive forms (Larner \& Laurie, 2010, p. 223). The intersecting and overlapping relations and interactions of MNLS are now part of the education reform process in Brazil. Nonetheless, this is a policy network that is under construction; "always in the process of being made ... never finished; never closed" (Massey, 2005, p. 9). The MNLS network draws on a variety of direct interpersonal social relations and

\footnotetext{
${ }^{2}$ http://movimentopelabase.org.br
} 
high levels of interpersonal trust and is animated by face-to-face interactions, that is various kinds of meetingness (Urry, 2003). Conferences, workshops, discussion groups are occasions for the reiteration, reinvigoration, and re-affirmation of discourse and allegiances, a shared language is borrowed/developed to re-name the social.

As examples of how meetings and events are used strategically to activate the network, we can highlight three formative seminars in the creation of MNLS (in a long series of events), organised by Lemann Foundation. The first was held in April 2013 at Yale University, in New Haven - USA, which is referred to by interviewees and on websites as the "creation moment" of MNLS. Titled "Leading Educational Reforms: Empowering Brazil for the 21st Century," the event gathered 35 participants, including members of Brazil's National Congress, state and municipal secretaries of education, officials from foundations and civil society organisations, and representatives of other stakeholders in Brazil's education system (Yale News, 2013³). The Brazilian group heard talks from Yale faculty, school administrators, policymakers, and reform advocates who had been part of the development and promotion of the Common Core Curriculum in the United States. According to the Yale News website, "during their time in New Haven, the participants discussed education reform in Brazil and developed an action plan they could implement upon returning home."

In October 2013 there was a "follow-up" event in Campinas, São Paulo - Brazil. This time, the conference focus was specifically on the development of common core curriculum standards. On this occasion it is reported that the conference participants were given "insider perspectives on the development of the Common Core State Standards in the U.S. by Susan Pimentel and Michael Cohen [...] who shared strategic lessons" (Yale School of Medicine News, $2013^{4}$ ). Pimentel was the main author of the Common Core for literacy and the vice chair of the National Assessment Governing Board that advises on the National Assessment of Educational Progress (NAEP), the U.S. national report card. Michael Cohen is the president of Achieve Inc., a non-profit organisation, funded by the Gates Foundation and the USA federal government. Achieve advocated for the Common Core Curriculum and participated in its writing process, and later crafted standardised tests and consulting aligned with the Common Core. Complementarily, on the very next day, another seminar was held in São Paulo, organised by CONSED and supported by the Lemann Foundation, held at Insper (a higher education institution) with the scholar Michael Young, from England, as the main speaker.

\footnotetext{
${ }^{3}$ http://news.yale.edu/2013/04/29/educational-reform-was-topic-new-yale-brazil-leadership-program

${ }^{4}$ http://medicine.yale.edu/news/article.aspx? $\mathrm{id}=6254$
} 
In March 2015, a further seminar was held at Yale, again organised by Lemann Foundation. Titled "Leading Educational Reforms: Opportunities and Challenges Ahead" this second Yale seminar, referred to as a "leadership program for Brazilian leaders" in Yale's website, it had 45 Brazilian public officials, as well as Lemann Foundation leadership and staff in a four-day seminar with lectures and workshops by "international education experts". In Yale's website the goal of this seminar are defined as: "to create an understanding of and consensus around the importance of improving education among Brazil's new political leadership at the national and state levels. In closed-door sessions, Brazilian senators, congressmen, governors, and education leaders discussed the country's pressing educational issues and strategized how to affect change" (World Yale News, 2015 $5^{5}$.

This series of events brought together a set of representatives from the field of new philanthropy and academia with a variety of civil servants and politicians from federal, state and municipal levels. Attendees were invited by Lemann Foundation, and a representative from this organisation described this creation process of MNLS in the following way:

"MNLS surfaced in 2013 with the goal of bringing the national common base to the public agenda in Brazil. Since we started this process [with MNLS] we have organised many meetings. Twice already we have taken a group of about 50 people for a weeklong immersion at Yale University. Back in 2013 that was how we started, we took a group of people to Yale to discuss curriculum, and there the Movement was created. Then last year [2015] we did it with people that were starting their mandates in January, state secretariats, federal deputies, state deputies, governors... These events are very common, [we do] many meetings, many talks to solve the main difficulties, exchange ideas, talk with the MNLS, but also talk with deputies, with the curriculum writing team, talk with everyone that is important in this debate" (Interview Lemann Foundation, 2016 - our emphasis).

Here we can see one way in which the foundation does its policy "work", and how they target and mobilise the actors they want to build a relationship with. These events are sites that support the creation, evolution and maintenance of a dynamic, unstable and expanding policy network, where new philanthropy, policy 'technocrats' and the state can interact. Also evident are the "chains of on going effort" (Fenwick, 2009) - meetings, events, conversations, visits, funding, alliances, etc. through which network relations are established and "held in place". These are also some of "the chains, circuits, networks, webs, and translations in and through

\footnotetext{
${ }^{5} \mathrm{http}: / /$ world.yale.edu/news/brazilian-leaders-gather-yale-discuss-public-education
} 
which policy and its associated discourses and ideologies are made mobile and mutable" (McCann \& Ward, 2012, p. 42). MNLS seeks to "teach" decision makers about the importance of a standard curriculum, and clearly points towards and "borrows" from the model of the USA Common Core. This series of events was aimed both at gathering support from different actors in different spaces and creating a shared belief in and commitment to the need for a national curriculum. Part of this ideological labour relied on the authority invoked by Yale University.

Further, the social aspect of such events, and trips, should not be neglected. They propel conversations and the building of trust, which are essential for the coherence of networks (see Avelar, Nikita, \& Ball, 2018 for a fuller discussion). As Marsh and Smith (2000, p. 6) put it, "networks involve the institutionalization of beliefs, values, cultures and particular forms of behaviour". These then are not simply pragmatic relations but also constitute moral and epistemic communities. Over time, members of this "community" have come to know each other well, work together and share the values which inform their choices and commitments; and they generate and share persuasive arguments that can be used in more hostile contexts (Grek, 2012, p. 56).

\section{MNLS members' affiliations}

MNLS is constituted of both people and institutions. The "institutional supporters" of the movement include 12 private organisations ${ }^{6}$ of different kinds, including new philanthropy organisations (family and corporate), research institutions and education civil servants associations. MNLS is funded by Lemann Foundation, Natura Institute and the bank Itaú BBA and, besides being part of the funding group, Lemann Foundation is the "executive secretariat" with the task of carrying out the decisions taken by the members. This last foundation was created in 2002 by the businessman Jorge Paulo Lemann (currently the richest Brazilian citizen and amongst the 25 wealthiest people in the world ${ }^{7}$ ), and started with local projects but soon shifted to large-scale and education policy goals. Both Lemann and Estudar foundations are known for adopting management strategies similar to Lemann's companies, with a culture of austerity and the pursuit of results (Correa, 2013). Its education agenda revolves around what Pasi Sahldberg (2011) calls GERM - the Global Education Reform Movement, with five highly interrelated features: "stardardisation of education", "focus on core subjects", "search for low

\footnotetext{
${ }^{6}$ Research associations - ABAVE and CENPEC, family philanthropy - Lemann Foundation, Roberto Marinho Foundation, Ayrton Senna Institute and Inspirare Institute, corporate philanthropy - Natura Institute and Unibanco Institute, civil servants associations - UNDIME and CONSED, corporate advocacy coalition - Todos pela Educacao, NGO - CEDAC

${ }^{7}$ https://www.bloomberg.com/billionaires/profiles/jorge-p-lemann/
} 
risk ways of teaching", "use of corporate management models" and "test-based accountability policies for schools" (Ball, Junemann, \& Santori, 2017, p. 2). The creation of a standard curriculum addresses all five principles, directly - the first three elements - or indirectly - the later two.

While the MNLS is fully funded and maintained by private organisations, its membership includes representatives from every level of government (federal, state, municipal as noted above). At the federal level, what is particularly striking is how many members of MNLS hold or have held positions in the National Council of Education, the Ministry of Education and the Câmara dos Deputados, the lower congress chamber. By the end of 2016, more than half of MNLS members were working in state institutions.

The individual members are key to the functioning of MNLS, both in setting its agenda, or strategically planning MNLS's goals' and strategies; as well as in the pursuit of this agenda in and through their diverse contexts and connections. Regarding the first, setting the agenda, according to a representative of Lemann Foundation, "the group of [individual and institutional] members decides what are the priorities for the year, the strategic decisions and this group follows up MNLS developments. The Executive Secretariat of the movement is in touch with these people everyday, literally, exchanging ideas everyday, asking for their opinions, for advice and suggestions" (Interview Lemann Foundation, 2016). Second, regarding the advancement of this agenda, the connections held by the members are fundamental for MNLS's "advocacy work". This is made explicit by the same representative of Lemann Foundation in saying:

"Each members of the movement is an advocacy potential. They are very different people, the movement is quite plural, so each one of these people has a very different set of "interlocutors". The members are the advocacy of the group because they talk with the most interesting interlocutors for them. There are people with greater dialogue with social movements, there are people with more dialogue with other foundations, some people talk with the government, some people are government. So the movement is an advocacy organism, it is very interesting that we say the same things, with different colours sometimes, but the principles are the same. Instead of having one advocacy, you have 60. This is very interesting. I believe one of the strengths of the movement is operating as a bloc. Even if we don't agree in everything, the key messages are always there, being repeated for those people that matter (in the debate)" (Interview Lemann Foundation, 2016). 
Thus, we would argue it is crucial that we consider MNLS's individual members to better understand how MNLS's discourses flow, paying attention to to/from where and to/from whom they move. Thus, there is below a co-affiliation network graph of the individual members of MNLS. The graph was built as an ego-network (the network of one institution, MNLS), meaning that all institutions have at least one connection with MNLS (at least one person affiliated to both institutions). For the sake of clarity, instead of including all edges, here we organized the nodes in three circles. In the outer-circle, institutions have only one connection to MNLS. In the middle-circle, they have two connections. Finally, in the central circle they have three or more (with the exact number presented numerically on the edge). The thicker the line, the more people in common these two organisations have. Node sizes vary according to how connected the institution is. The nodes are placed according to their institution type, organised as follows in a clock-wise order, starting from the top of the circle: universities/research institutions, business companies, foundations, municipal governments, state governments, federal government and international organisations.

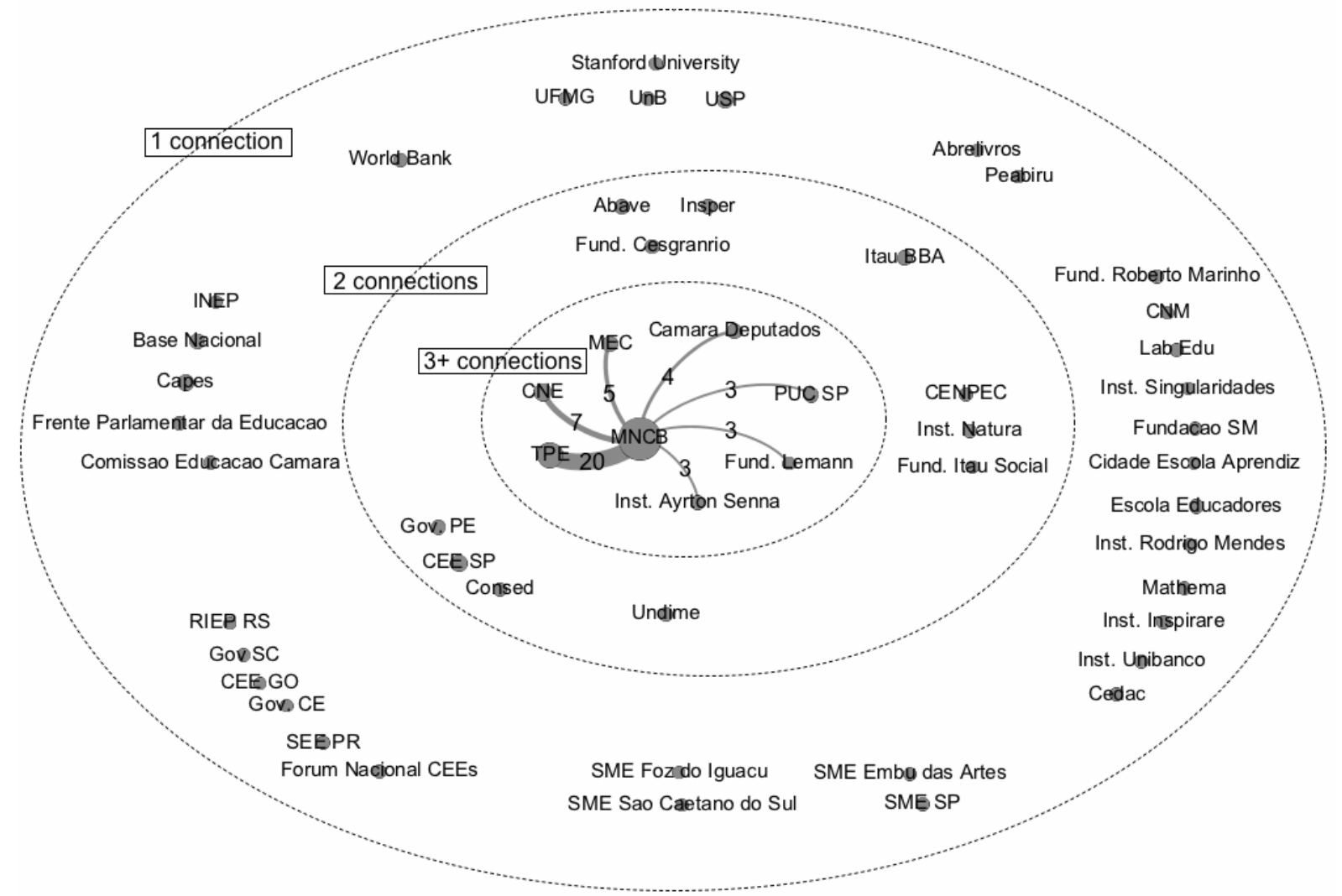

Figure 1. MNLS co-affiliation ego-network

In Figure 1 we see the co-affiliation of members between MNLS and 52 other institutions. Out of these organisations, seven have more than 3 connections with MNLS (and 
are therefore more likely to have a significant exchange of ideas, discourses and/or resources). Todos pela Educação (TPE), a large and influent corporate advocacy organisation (see Martins \& Krawczyk, 2016), unquestionably has the highest co-affiliation with MNLS (20 members), indicating the close relationship between the two movements. Interestingly, among the more connected institutions, there are three federal ones: Câmara dos Deputados, MEC and NCE.

To further explore the blurred relation between private and public, new philanthropy and government, present in MNLS's network, in what follows we discuss the evolution of this part of the network in a time-span. We also consider the backgrounds and affiliation of some of these members to address how MNLS came to build this network with such a close relationships with fundamental public institutions, specially MEC and the NCE.

\section{MNLS and MEC/NCE: the network's change in time}

In spite of claiming to have been created in 2013, MNLS only began using this name in events and publishing information about its work (and supporters) in the second semester of 2015. Thus, the listings here begin from September 2015, the first time MNLS published the names of its supporters, and the data was organised in three semesters according to the identified changes in its composition. Even in this short period of time, we can see considerable shifts in the composition of MNLS and the increasing numbers of civil servants. Indeed, the amount of change in three semesters is a good example of how these networks are ever changing, unstable and fluid (Ball, 2012; Peck \& Theodore, 2010). In Figure 2 below we see the change in MNLS's composition. 


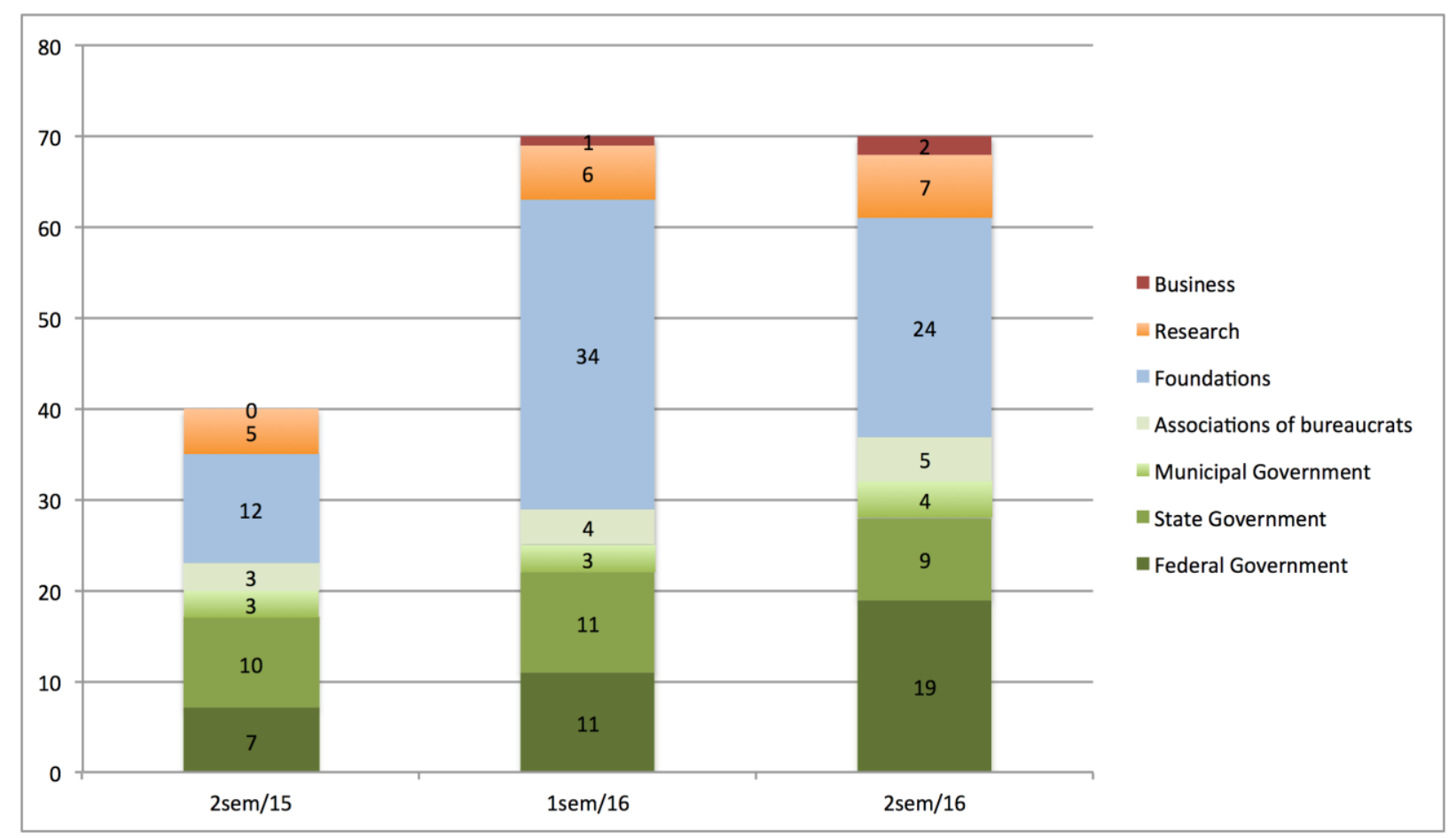

Figure 2. Composition of MNLS between 2015 and 2016

Two changes in the composition of MNLS become visible through Figure 2. The first regards an overall growth in the movement membership, evident in the difference between the second semester of 2015 to the beginning of 2016. In this period, the movement grew from 40 to 70 members. This growth was mainly achieved through the recruitment of foundation representatives: out of the 30 new members, 24 were affiliated to foundations. Regarding civil servants, although the overall growth was not as substantial, it is important to stress that by the end of 2015, MNLS recruited 4 members of the NCE. In this period, MEC had just published the first version of the Base (September 2015), which created a widespread public debate. MEC, MNLS and local authorities were fomenting discussions through several small seminars and meetings to gather feedback for a second version of the Base document.

In contrast, the second shift in the MNLS's composition is qualitative. While in the first semester of 2016 there were 29 members affiliated to state institutions and 41 to private organisations, in the following semester it changed to 37 members in state institutions and 33 in private ones. Most importantly, MNLS's composition changed with the addition of members occupying vital posts in the federal government (NCE and MEC). This shift took place in some kind of relation to the controversial change of government, when President Dilma Rousseff was impeached and a conservative administration took over. From only 7 members in federal 
government positions in the first semester of 2015, MNLS reached 19 by the second half the year.

Below there are three affiliation networks between MNLS, MEC and NCE (and its two chambers, as noted before). Differently from the first network graph (Figure 1), the ones below were kept as two-mode graphs, with two sets of nodes (institutions and people). Here we aim at exploring how MNLS's co-affiliations with these vital federal decision-making institutions have been built over time.

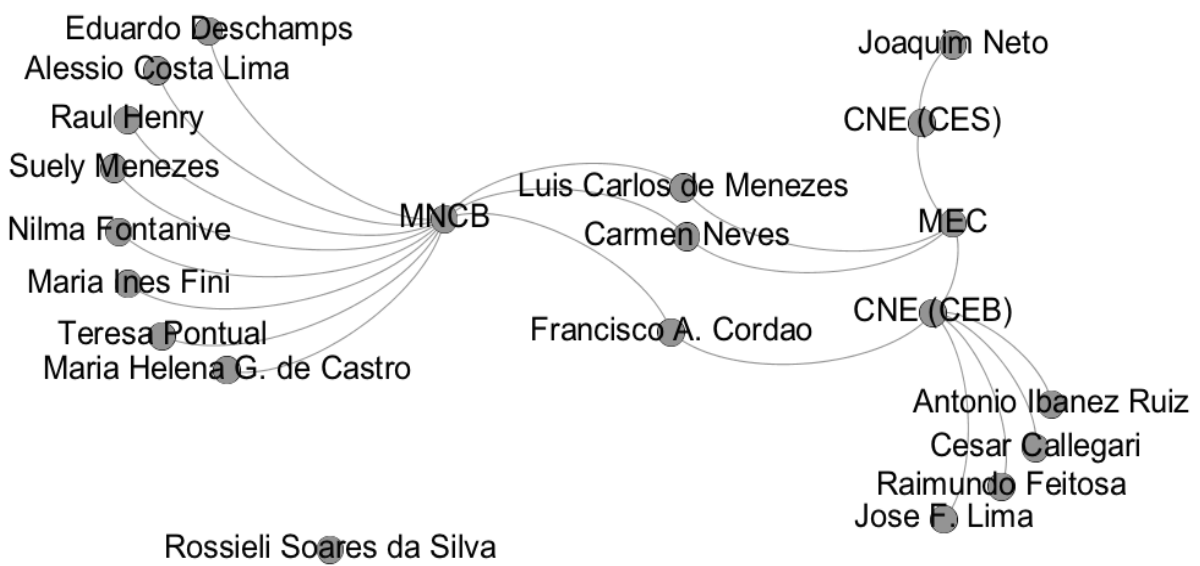

Figure 3. MNLS and MEC - 2nd semester 2015

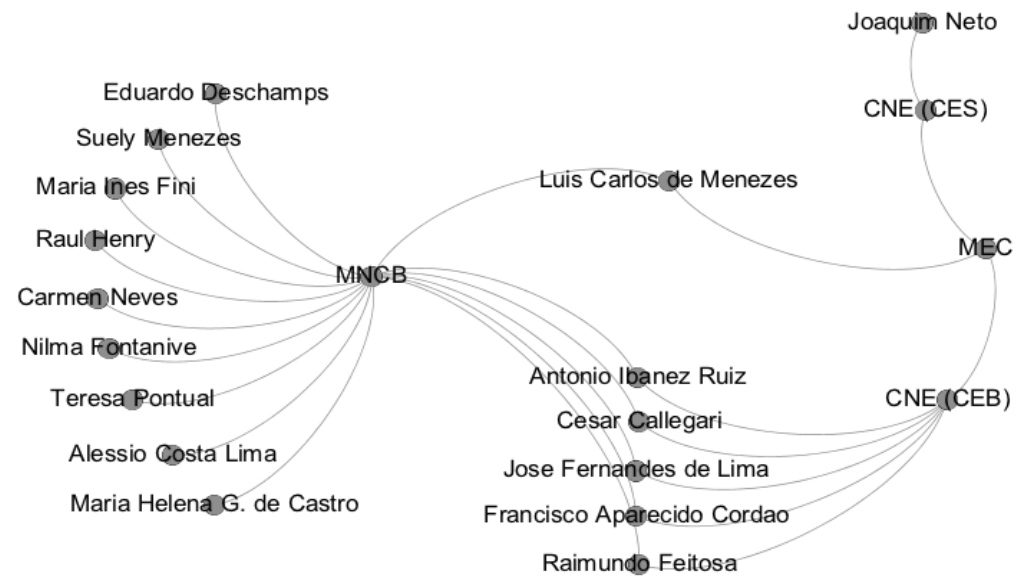

Rossieli Soares da Silva

Figure 4. MNLS and MEC - 1st semester 2016 


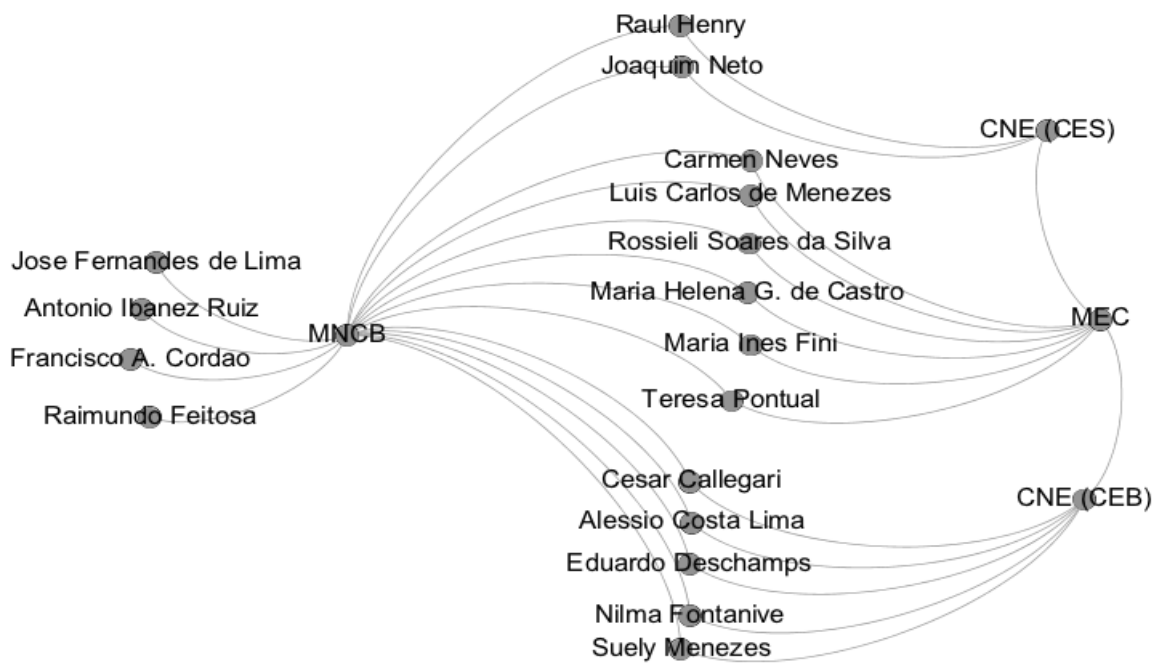

Figure 5. MNLS and MEC - 2nd semester 2016

MNLS had two different directions of interaction with government civil servants. First, up to the end of 2015 (see change from figures 3 to 4) MNLS was recruiting them into the movement, i.e. people who were on the NCE and then became affiliated to the movement. In an interview with a representative from Lemann Foundation, we see how this creation of relationships with relevant policymakers is a deliberate and planned tactic. He explains how Lemann Foundation and MNLS had been investing in relationship-building in Brasilia, Brazil's capital: "We have a person, we hired someone "super", who is now in Brasilia lobbying. [...] He has in his diary talking to people that have power, or people that participate in the process of eventually having connectivity" (Interview Lemann Foundation, 2016).

Second, in a new policy window (Kingdon, 2003) - the changing government - people who were already part of the MNLS were appointed to roles in the bureaucratic structure, indeed to strategic positions in NCE and MEC, both official sites for deliberation and formation of the new national curriculum. MNLS members were appointed to the following positions in MEC: MEC's Executive Secretary, the head of the Secretariat of Basic Education (SEB), as well as two out of the three SEB's sub-secretaries, and INEP's presidency. Regarding NCE, while in June 2016 the NCE biannual nomination by the President was to take place, Michael Temer, at the time interim president, altered Roussef's nominee list (after its publication, but before it got enacted, changing half of the 12 new nominees). In his new list, there were four names affiliated to private institutions, including Nilma Fontanive and Suely Menezes, both members of MNLS. 
In both directions of interaction the epistemic relation between the movement and members has been fundamental. Francisco Aparecido Cordão, the first NCE member to join MNLS, was part of the founding team of Todos pela Educação. Similarly, Cesar Callegari, who was part of the group from NCE that joined MNLS by the end of 2015 (see figure 4), is in the governance team of Todos pela Educação. In the second shift (see figure 5), we see Nilma Fontanive, who is part of the technical commission of Todos pela Educação, and Suely Menezes, who is part of the large private higher-education chain Ipiranga.

However, the most significant examples of boundary-spanning actors in this network are probably Maria Helena Guimarães de Castro and Maria Ines Fini. Both joined MNLS at its early stages, both are now in high-ranking positions in MEC, and both have a long and complex history within Brazilian education policy, with a vast set of connections with both the public and the private sectors. Castro has worked as a professor of political science at the University of Campinas. She has been the president of INEP during the government of Fernando Henrique Cardoso (1995 - 2001), when large-scale public examinations were introduced, and in 2002, during the same government, she became the Executive Secretary of MEC (position she holds again now) (Souza \& Oliveira, 2003). She has worked in different states and secretariats, including the secretariat of education in the state of São Paulo, when the state introduced a standard curriculum. She then joined the foundation Educar para Crescer, became president of the Fundação Sistema Estadual de Análise de Dados (SEADE, or State System of Data Analysis Foundation), and is part of Todos pela Educação. Maria Ines Fini also worked at the University of Campinas between 1972 and 1996, where she participated in the creation of the Faculty of Education. Between 1996 and 2002 she worked in INEP with Maria Helena de Castro, where she was a director responsible for introducing two large-scale tests. She also worked in different states and cities and was PISA's director in Brazil. She then became involved in several different foundations (FEAC, Campinas pela Educação, F\&F Educare, Roberto Marinho Foundation) and private high-education institutions (Cesgranrio, SL Mandic). Both actors are thus highly connected within and across the field of education in Brazil, who have accumulated a significant volume of network capital (Williams, 2002), having operated in different states, with different governments and worked in both public and private organisations. Both represent a specific, coherent and aggressive project of educational reform, one that values standardised teaching, large-scale testing, and the participation of private organisations in public education.

To make it clear, as is often the case in policy networks, in the MNLS network there is an epistemic commonality among members (Santori et al, 2015), one that is often manifested 
in affiliations, but also transcends them. Network members are bonded together through a shared view of what education should be, what the policy problems in Brazil are, and the necessary policy solutions. As an interviewee explains: "these organisations are in the movement because they truly believe that having a Common Base in Brazil can make a lot of difference. So they make this part of their own cause. Then it becomes a natural work to take this with them in whatever task or event they do" (Interview Lemann Foundation, 2016).

Here the boundary between the state and new philanthropy is becoming increasingly porous, and indeed we might say that MNLS emerges over time as a key site of policy and of state work in its own right. We also see the role of a relatively new kind of hybrid, boundaryspanning actor who manages "within inter-organisational theatres", as Williams (2002, p. 104) puts it, accumulating network capital as they move between sectors. At the same time new kinds of careers, identities and mobilities are forged within the processes of reform and through the work of such policy networks. These boundary-spanning and mobile policy actors contribute symbolically and substantively to a "power narrative" (McCann, 2008, p. 5) made up of ideas, practices and sensibilities that address the reform of the Brazilian school curriculum. Some we might identify as "movers and shakers" (Williams, 2002) - that is people who have the ability to connect and ensure cooperation within and across different networks by sharing common goals and combining resources. Individual trajectories and histories become embedded in the network, and focussed at particular nodal points. These are in effect embodied policy mobilities, these people carry the sensibilities and substance of education reform with them.

\section{MNLS, new philanthropy and civil servants: the heterarchical state in practice}

What we have sought to capture here is some aspects of a more general set of changes in the forms and modalities of the Brazilian state. These are not absolute changes, but rather a set of shifts in the balance or mix between the different elements of government - bureaucracy, markets and networks. The new mix brings a fragmented array of new players from business and philanthropy into the work of education governance and entangles bureaucratic actors in new sites of policy and new kinds of relations in and with policy. To reiterate, the work of groups like the MNLS does not signal once and for all systemic changes in education policy making or the education state, rather this is part of a myriad of small moves, experiments and initiatives that may be scaled up, and contribute over time to a more profound system reengineering. Far from a dramatic "roll-back" or a total "hollowing out" of the state (Holliday, 2000), this newly emerging model of governance implies a steady but undramatic "roll-out" of new structures and technologies of governance that are contributing to the redefinition of the 
roles and responsibilities of the state but, at the same time, resituate the state strategically in both normative and institutional terms.

These shifts are part of a deeper transformation of the political sphere, the "degovernmentalisation of the state" (Rose, 1996), such that the state no longer acts as the centre of power, rather new forms of political organization - heterarchies - are developing, in which governments no longer exert monopolistic control over state work but are becoming "metagovernors". "The new heterarchical mode of governance implies a conception of policy that should be seen as the collective efforts of a set of players who compete and form alliances in an ever-increasing networked political arena" (Olmedo, 2014, p. 253). This involves changes both in "who governs" and at the same time "how power is exercised". It occurs through the repopulating and reworking of existing policy networks and the emergence of new networks that give legitimacy to the role of business, enterprise and/or philanthropy in the solution of intransigent problems (like the form and content of the school curriculum).

This is a move beyond both bureaucratic and market forms of coordination towards more flexible, asymmetric, heterarchical relationships, within which responsibilities and processes of decision-making are shared by a heterogeneous mix of old and new policy actors, with the effect of re-balancing the governance mix (Ball and Junemann, 2012). As Jessop (1998, p. 32) explains:

"... the recent expansion of networks at the expense of markets and hierarchies and of governance at the expense of government is not just a pendular swing in some regular succession of dominant modes of policy-making. It reflects a shift in the fundamental structures of the real world and a corresponding shift in the centre of gravity around which policy cycles move."

What we have sought to indicate in particular here is both one new centre of gravity in the topography of education policy in Brazil and the concomitant formation of new kinds of mobile interstitial policy actors who operate across and between what were once distinct sectors.

Also evident here in the formation and evolution of the MNLS is the construction of what Cook and Ward (2012) call policy pipelines. Through these transnational policy pipelines extending from the USA to Brazil, mainly mediated by Lemann Foundation, Yale University and US policy entrepreneurs, pass both tacit knowledge and knowledge in more codified forms. This "learning acquired through participation in trans-urban policy pipelines dissipates through the different "local" clusters of practitioners and policy makers" (Cook \& Ward, 2012, p. 141) - in this case the idea of a standard national curriculum. Thus, we might view MNLS as one 
small part of a more extensive joined-up policy network, which is a "globally integrated network" (Urry, 2003) of highly interdependent actors and organisations, practices and forms, which are related together in diverse ways in relation to education reform. This approximates to what Pasi Salhberg (2011) calls GERM - the global education reform movement. These network relations are not outside or over and against the local in any simple sense, they have multiple changing relations to and within "the local", or in fact different locals (national, state and municipal). Indeed, what is local and global is changed/muddied by the relationships and movements traced here. The work of the network, in its global sense, produces what Lingard and Sellar (2014) call new topologies of policy. Policy "space is configured through the intersection of global and situated elements" (Ong, 2007, p. 5). All of this is a re-working, or perhaps even an erasure, of the boundaries of state, economy and civil society.

The Brazilian case of education reform is joined up, practically and discursively, in a variety of ways, some described in this account, to a global network of policy ideas and forms of policy. Brazil is at one particular point on a continuum of change that interconnects and replicates a global shift in the form and modalities of the state and concomitant ways of governing differently. The specifics of our account would suggest a clear direction of travel with the work of the state increasingly being done elsewhere by other actors - all of which calls into question the relations between policy, the policy process and democratic politics. This is in some senses a de-politicisation of policy. New unelected and, in many ways, unaccountable voices are having a significant say in determining the methods, contents and purposes of education. MNLS members and its cohorts and partners are in some respects "voting with dollars" (Saltman, 2010). That is to say, financial, reputational and social resources are being deployed to change the landscape of education in Brazil and the experience of education in Brazilian schools. In such opaque public-private relationships it becomes challenging, if not impossible, to precisely identify the role played by different policy actors and hold them accountable. For example, although we agree with Peroni and Caeteno (2016) that Lemann Foundation, as the Executive Secretary of MNLS, has had a prominent role in the Movement and in the formulation of the Base, it has not been possible to ascertain its role in steering MNLS's agenda and its network building. In this sense, there is an urgent need for more research that focuses on new sites, new actors and new processes of policy beyond the state itself, and indeed beyond the nation state, as education policy research, in Brazil and elsewhere, generally continues to be focused on the state itself and traditional policy actors and processes. Concomitantly, research needs to develop a new repertoire of methods and 
techniques that are appropriate to the study of flows of policy rather than structures of government.

\section{Acknowledgements}

This 'case study' is part of a broader enquiry into the role of foundations in Brazilian education policy, conduct by Marina Avelar for her $\mathrm{PhD}$ at the UCL Institute of Education, which is funded by the CAPES Foundation, from the Brazilian Ministry of Education.

\section{Reference list}

Adrião, T., Peroni, V., \& da Costa, M. (2005). O público e o privado na educação: interfaces entre estado e sociedade. Xamã.

Arretche, M. T. (1996). O mito da descentralização: maior democratização e eficiência das políticas públicas. Revista Brasileira de Ciências Sociais, 31, 37-49.

Au, W., \& Ferrare, J. J. (2015). Mapping Corporate Education Reform: Power and Policy Networks in the Neoliberal State. Routledge.

Avelar, M., Nikita, D. P., \& Ball, S. J. (2018). Education policy networks and spaces of "meetingness": a network ethnography of a Brazilian seminar. In Global Education Policy and International Development (2nd ed.). London: Bloomsbury Publishing Plc.

Ball, S. J. (2012). Global education inc: New policy networks and the neo-liberal imaginary. Routledge.

Ball, S. J., \& Junemann, C. (2012). Networks, New Governance and Education. Policy Press.

Ball, S. J., Junemann, C., \& Santori, D. (2017). Edu.net: Globalisation and Education Policy Mobility. Taylor \& Francis.

Ball, S. J., \& Olmedo, A. (2011). Global Social Capitalism: using enterprise to solve the problems of the world. Citizenship, Social and Economics Education, 10(2-3), 83-90.

Bevir, M. (2011). Governance as theory, practice, and dilemma. The Sage Handbook of Governance. London: Sage, 1-16.

Bishop, M., \& Green, M. (2010). Philanthrocapitalism: How giving can save the world. Bloomsbury Publishing USA.

Borgatti, S., \& Halgin, D. (2012). Analyzing Affiliation Networks. The Sage Handbook of Social Network Analysis. Sage Publications.

Cook, I. R., \& Ward, K. (2012). Conferences, informational infrastructures and mobile policies: the process of getting Sweden "BID ready." European Urban and Regional Studies, 19(2), 137-152.

Correa, C. (2013). Sonho grande: Como Jorge Paulo Lemann, Marcel Telles e Beto Sicupira revolucionaram o capitalismo brasileiro e conquistaram o mundo. Sextante.

Freitas, L. C. de. (2012). Os reformadores empresariais da educação: Da desmoralização do magistério à destruição do sistema público de educação. Educ. Soc, 33(119), 379-404.

Hogan, A., Sellar, S., \& Lingard, B. (2015). Network restructuring of global edu-business: The case of Pearson's Efficacy Framework. W. Au, \&JJ Ferrare, Mapping corporate 
education reform. Power and policy networks in the neoliberal state. Routledge, 4364.

Jessop, B. (2011). Metagovernance. In The Sage handbook of governance. SAGE.

Jessop, B. (1998). The rise of governance and the risks of failure: the case of economic development. International social science journal, 50(155), 29-45.

Knox, H., Savage, M., \& Harvey, P. (2006). Social networks and the study of relations: networks as method, metaphor and form. Economy and Society, 35(1), 113-140.

Larner, W., \& Laurie, N. (2010). Travelling technocrats, embodied knowledges: Globalising privatisation in telecoms and water. Geoforum, 41(2), 218-226.

Lingard, B., \& Sellar, S. (2014). Representing your country: Scotland, PISA and new spatialities of educational governance. Scottish Educational Review, 46(1), 5-11.

Lingard, B., Sellar, S., \& Savage, G. C. (2014). Re-articulating social justice as equity in schooling policy: The effects of testing and data infrastructures. British Journal of Sociology of Education, 35(5), 710-730.

Macedo, E. (2014). Base Nacional Curricular Comum: novas formas de sociabilidade produzindo sentidos para educação. Revista E-Curriculum, 12(3), 1530-1555.

Macedo, E. (2016). In favor of a topological reading of curriculum policies. Education Policy Analysis Archives, 24(0), 26.

Marcus, G. E. (1995). Ethnography in/of the world system: The emergence of multi-sited ethnography. Annual Review of Anthropology, 24(1), 95-117.

Martins, E. M., \& Krawczyk, N. R. (2016). Entrepreneurial Influence in Brazilian Education Policies. World Yearbook of Education 2016: The Global Education Industry, 78.

McCann, E., \& Ward, K. (2012). Assembling urbanism: following policies and "studying through" the sites and situations of policy making. Environment and Planning A, $44(1), 42-51$.

Olmedo, A. (2014). From England with love... ARK, heterarchies and global "philanthropic governance." Journal of Education Policy, 29(5), p575-597. 23p.

Olmedo, A. (2017). Something old, not much new, and a lot borrowed: philanthropy, business, and the changing roles of government in global education policy networks. Oxford Review of Education, 43(1), 69-87.

Ong, A. (2007). Neoliberalism as a mobile technology. Transactions of the Institute of British Geographers, 32(1), 3-8.

Peck, J., \& Theodore, N. (2010). Mobilizing policy: Models, methods, and mutations. Geoforum, 41(2), 169-174.

Peck, J., \& Theodore, N. (2012). Follow the policy: a distended case approach. Environment and Planning A, 44(1), 21-30.

Peroni, V. M. V. (Ed.). (2013). Redefinições das fronteiras entre o público e o privado: implicações para a democratização da educação. Brasília: Liber Livro.

Peroni, V. M. V., \& Caeteno, M. R. (2016). O público e o privado na educação - Projetos em disputa? Retratos da Escola, 9(17).

Prell, C. (2012). Social Network Analysis: History, Theory and Methodology. SAGE. 
Reckhow, S., \& Snyder, J. W. (2014). The expanding role of philanthropy in education politics. Educational Researcher.

Rhodes, R. A. W. (1996). The new governance: governing without government. Political studies, 44(4), 652-667.

Robertson, S. L., \& Verger, A. (2014). The Emergence of Public Private Partnerships in the Global Governance of Education Educação \& Sociedade, 33(121), 1133-1156.

Sahlberg, P. (2011). The Fourth Way of Finland. Journal of Educational Change, 12(2), 173185.

Saltman, K. (2010). The gift of education: Public education and venture philanthropy. Springer.

Santori, D., Ball, S. J., \& Junemann, C. (2015). mEducation as a site of network governance. Mapping Corporate Education Reform: Power and Policy Networks in the Neoliberal State, 23-42.

Shiroma, E. O. (2013). Networks in action: new actors and practices in education policy in Brazil. Journal of Education Policy, 29(3), 323-348.

Souza, S. Z. L. de, \& Oliveira, R. P. de. (2003). Políticas de Avaliação da Educação e QuaseMercado no Brasil. Educação \& Sociedade, 24(84).

Urry, J. (2003). Social networks, travel and talk. British Journal of Sociology, 54(2), 155175. 